\title{
A DIMENSÃO ESQUECIDA DO TRABALHO: ENTREVISTA COM JAIME SANTOS JÚNIOR
}

\author{
Guillermo Stefano Rosa Gómez ${ }^{1}$ \\ Felipe Rodrigues $^{2}$ \\ Manoel Cláudio da Rocha ${ }^{3}$
}

\section{Apresentação: Trajetórias intelectuais e Antropologias do Trabalho}

Esta entrevista com o professor e sociólogo Jaime Santos Junior (UFPR) está associada a uma proposta de mapeamento e de consolidação de redes de pesquisa em torno do fenômeno do trabalho na América Latina. Dentre as atividades que foram promovidas e organizadas com este intuito estão a realização do curso $A$ (Re)Produção social das Masculinidades, no Centro de Pesquisa e Formação do Sesc São Paulo ${ }^{4}$ em julho 2019 e a participação na XIII Reunião de Antropologia do Mercosul (RAM) realizada em Porto Alegre de 22 a 25 de julho de 2019, período em que aconteceu a entrevista. Na RAM, Jaime integrou a mesa redonda Envelhecimentos narrativos e engajados: Memórias de trabalho e resistência ${ }^{5}$, e participou do grupo de trabalho Antropologias Latino-americanas do trabalho: desafios para a construção de conhecimentos críticos desde o sul ${ }^{6}$.

A entrevista com Jaime, que é graduado em Ciências Sociais (UFS/2003) com mestrado (UFS/2007) e doutorado em Sociologia (USP/2014), discorre sobre diferentes aspectos de sua trajetória de pesquisa, ressaltando a importância de uma ciência social atenta às "zonas cinzentas" dos mundos do trabalho, propondo um olhar para os interstícios e os não-ditos. Suas pesquisas sobre trabalhadores do corte de cana em

\footnotetext{
${ }^{1}$ Universidade Federal do Rio Grande do Sul, Brasil. Email: guillermorosagomez@gmail.com ORCID id: https://orcid.org/0000-0003-2902-9993

${ }^{2}$ Universidade Federal do Rio Grande do Sul, Brasil. Email: felipe.editoracao@gmail.com ORCID id: https://orcid.org/0000-0003-3646-7641

${ }^{3}$ Universidade Federal do Rio Grande do Sul, Brasil. Email: manoelrochacs@gmail.com ORCID id: https://orcid.org/0000-0002-8477-6062

${ }^{4}$ Com a presença de Hernan Palermo, Marilda Menezes, Jaime Santos Junior e Guillermo Gómez. Mais informações em: https://centrodepesquisaeformacao.sescsp.org.br/atividade/a-re-producao-social-dasmasculinidades.

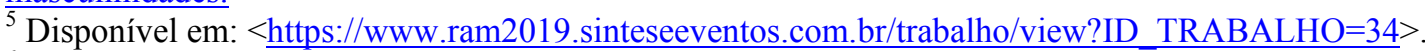

${ }^{6}$ Disponível em: $<$ https:/www.ram2019.sinteseeventos.com.br/simposio/view?ID SIMPOSIO=6 $>$.
} 
Sergipe, sobre operários migrantes no $\mathrm{ABC}$ paulista ou, ainda, sobre as memórias operárias dos ciclos de greves em Pernambuco e São Paulo - realizadas sempre em interlocução com uma rede de pesquisadoras e pesquisadores -, destacam a relevância do estudo do cotidiano e de suas resistências. A narrativa do entrevistado enfatiza um esforço de realizar uma sociologia do trabalho "que não quer ser apenas uma sociologia da denúncia".

Tivemos o objetivo de tornar a entrevista um texto acessível, com o propósito de divulgar o pensamento desse intelectual e possibilitar usos didáticos do material. Pautamos a entrevista inspirados em temas e categorias consolidadas em nossos espaços de formação - o Núcleo de Antropologia Visual (Navisual/PPGAS/UFRGS) e o Banco de Imagens e Efeitos Visuais (https://www.ufrgs.br/biev/) - tais como as trajetórias intelectuais e seus campos interpretativos, as linhagens teórico-conceituais, os pertencimentos institucionais, as biografias e as escolhas temáticas ${ }^{7}$.

Dessa mesma maneira, nos lançamos à tarefa de provocar os pesquisadores e as pesquisadoras dos mundos do trabalho a partir do campo da Antropologia Visual, refletindo sobre suas produções de imagens durante a pesquisa. Temos a intenção de considerar criticamente as imagens que as Antropologias e Sociologias do Trabalho na América Latina estão produzindo e interpretando ${ }^{8}$. Por ser a imagem uma categoria cara a nós, foi impossível dissociar a trajetória biográfica e intelectual de Jaime Santos de seus acervos imagéticos. Se os temas "biográficos" evidenciam e provocam questões que o "perseguem", estas imagens, produzidas em campo e/ou de seu acervo pessoal, vibram em suas reflexões.

Iluminuras: Damos início à entrevista com o professor Jaime Santos Junior. Bem-vindo à Porto Alegre, bem-vindo à RAM. Queria começar primeiro agradecendo a sua disponibilidade de dar essa entrevista. Nossa ideia é relatarmos no nosso dossiê da Revista Iluminuras, para pensarmos um pouco as antropologias e sociologias do trabalho. Os objetivos dessa entrevista são os de convidá-lo a pensar sobre tua

\footnotetext{
${ }^{7}$ Tomamos como inspiração o projeto Narradores Urbanos, olhares em Antropologia Urbana, realizado entre os anos 2005 e 2011 e coordenado por Cornelia Eckert e Ana Luiza Carvalho da Rocha que "apostou nas narrativas fílmicas para acompanhar as trajetórias de intelectuais como Ruben Oliven, Teresa Caldeira, Gilberto Velho e Eunice Durham em seu processo de rememoração da trajetória na consolidação da Antropologia Urbana como campo de estudo no corpus da produção das ciências sociais brasileira e mundial." (Gómez; Baldissera; Rodrigues, 2019).

${ }^{8}$ Iniciamos um primeiro movimento nessa direção em nossa publicação sobre a professora e antropóloga Cornelia Eckert, publicado na Revista Latinoamericana de Antropología del Trabajo (Gómez; Baldissera; Rodrigues, 2019).
} 
trajetória, como é que chegaste nos temas do trabalho e o que tens feito agora. Entender um pouco o teu trajeto intelectual e também tuas influências. Então começaria com uma pergunta aberta, voltada pra ti contar para nós da tua trajetória intelectual e acadêmica mas se quiser falar um pouco de onde tu vens, do contexto familiar que leva a chegar nas Ciências Sociais e nos temas do trabalho.

Jaime: Queria agradecer pela oportunidade de estar aqui contando um pouco sobre a minha história, minha trajetória, uma categoria que é cara pra mim também, né? Falar de trajetórias de vida. Eu, motivado a pensar sobre minha própria trajetória, vou propor uma narrativa que vai conjugar alguns aspectos da minha vida pessoal e familiar com o outro lado da minha trajetória acadêmica ou propriamente intelectual. Para isso, eu costumo dizer que eu talvez tenha sido muito influenciado pela trajetória de meu pai. Eu sou filho de um caminhoneiro do nordeste, ele nasceu numa cidade pequena do interior de Sergipe. Eu sou o único da família que nasceu em Aracaju, os meus irmãos nasceram ainda em cidade do interior onde minha família morava, até que se deslocou para Sergipe. Sou o que chamamos no nordeste de filho "raspa de tacho", ou "temporão", há muitos apelidos pra isso, "ponta de rama”, são vários os apelidos. Sou também o único que acompanhei a trajetória de meu pai já na fase final do trabalho dele, e não toda a fase que meus irmãos pegaram - somos 6 filhos -, talvez mais na fase áurea do trabalho dele. Mas ainda assim, mesmo nessa fase em que ele já estava saindo do trabalho como motorista de caminhão, como caminhoneiro, eu fui muito marcado pela maneira como ele se relacionava com o trabalho. Sobretudo, por esse aspecto de ter viajado pelo Brasil todo e ter conhecido um Brasil que não era o Brasil que eu lia nos livros da escola. Porque as histórias que o meu pai contava do Brasil que ele conhecia, algumas coincidiam com o Brasil que eu tinha visto nos livros de escola, mas as relações que meu pai tinha com os presidentes e com o que era o estado de São Paulo o estado da Bahia, os outros estados do Nordeste, as outras regiões do Brasil, em muito diferia a maneira como ele narrava daquilo que eu lia propriamente nos livros. Porque era sempre uma narrativa com muitos traços, eu diria não só folclóricos, mas também literários, a maneira como ele construía esse percurso nas viagens.

Como qualquer criança, eu também era motivado a entrar naquele caminhão e fazer algumas dessas viagens com ele. Minha mãe nunca deixou, porque essa era uma decisão que era gerida um pouco em família. Minha mãe descende de uma outra família, um pouco mais, digamos, aburguesada. Meu pai uma pessoa mais simples. E minha mãe 
tinha muito essa preocupação com os estudos dos filhos, dos meninos. Ela me permitiu fazer algumas dessas viagens nas minhas férias escolares. Então, eu costumo dizer que o livro que eu escrevi na tese (São Paulo: Annablume, 2017), o trabalho no corte de cana de açúcar, talvez eu deposite aí esse primeiro interesse pela questão com a qual seja, de fato, o núcleo dos meus interesses intelectuais, que é essa relação entre vida e trabalho.

Muito na perspectiva de como os sujeitos experienciam, ou atribuem significados ao trabalho que exercem. Porque eu vi muito meu pai forjar a vida dele, construir uma narrativa sobre ele mesmo, em torno da profissão de caminhoneiro. É como se a órbita do mundo girasse em torno do que ele foi. Isso se desdobra até hoje. Ele já está com 89 anos, mas ele volta a contar todas as histórias da vida dele.

Bom, eu acho que aquilo despertava um interesse em mim e eu costumo dizer que quando eu conheci o trabalho na cana dormindo [pausa]... Eu não sei se vocês conhecem a boleia de um caminhão, um caminhão um pouco mais antigo. Meu pai dormia no piso do caminhão e eu conseguia dormir numa rede que há, ela é montada dentro da cabine do caminhão. Chegávamos muito cedo à usina e meu pai parava o caminhão ali, dava pra dormir mais um pouco. A primeira lembrança que me vem das usinas é pelo nariz, é olfativa. Porque o ambiente não é só barulhento, ruidoso, ele é, sobretudo, olfativo. É uma impressão muito forte que vem do cheiro do mel produzido ali, de todo processo produtivo que exala um cheiro forte de odores, também dos corpos que estão ali, certamente. Bom, uma vez que você entra na usina e vai conhecendo aqueles trabalhadores... Então eu acho que nasceu dali essa inquietação que me levou a fazer Ciências Sociais. 

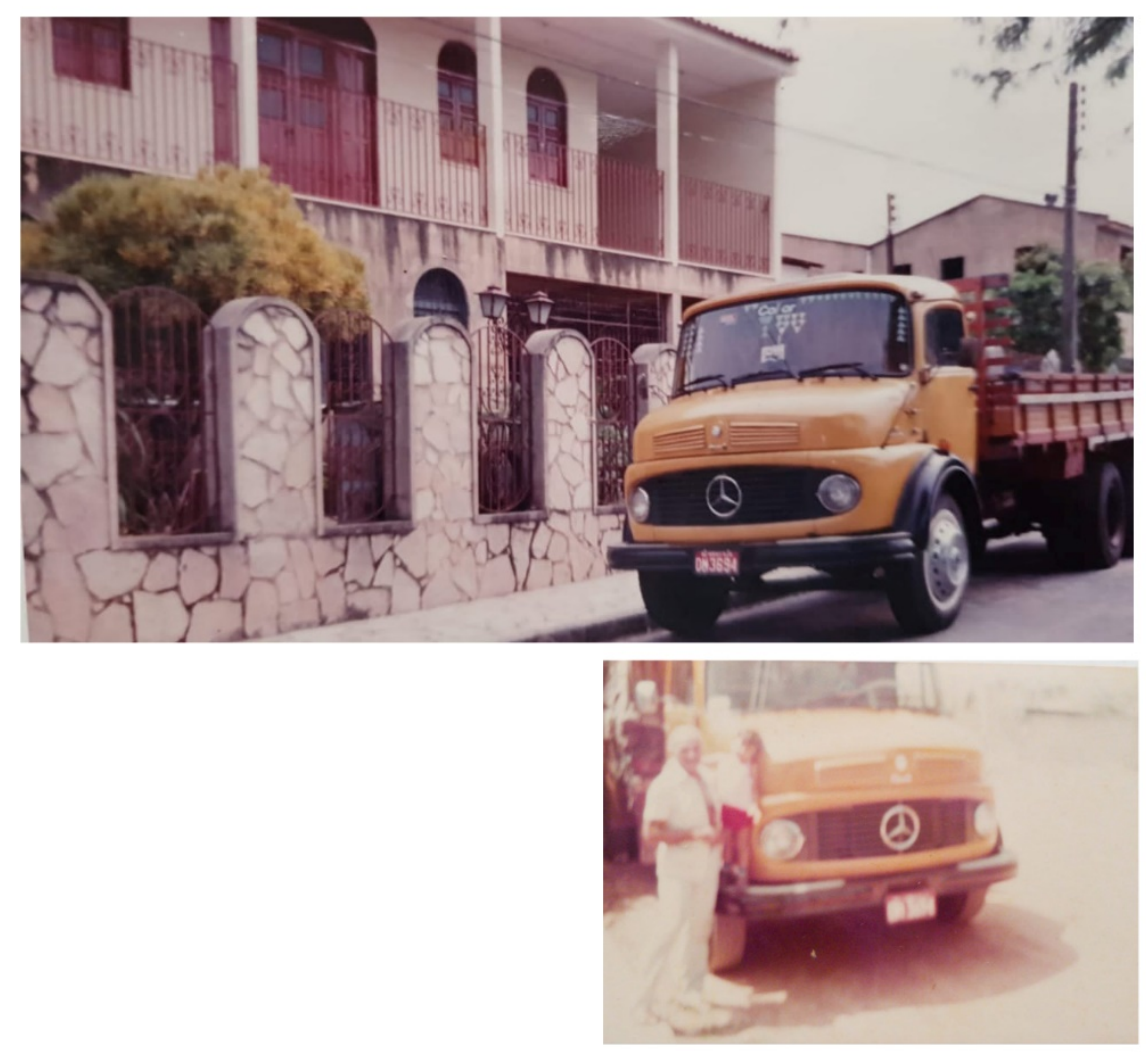

Imagem 1 - Acervo pessoal de Jaime Santos Junior.

Eu sempre gostei muito de História, eu não consigo racionalizar muito como foi que eu fui parar na Sociologia, porque eu nunca tinha feito Ciências Sociais antes, nunca vi Sociologia na escola, mas gostava muito de História. Também há duas trajetórias de dois irmãos meus muito marcadas por essa narrativa de trabalho. Eles eram petroleiros da Petrobrás. E também me impactava a maneira como eles se relacionavam com a empresa e com o trabalho, que é muito específica do contexto da presença da Petrobrás em Sergipe. Eles pegaram a fase áurea da empresa. Eu, jovem, certamente era marcado por essas histórias que eles narravam da vida deles no trabalho, do que representava o trabalho. E eu faço um primeiro movimento, ainda muito imaturo, muito juvenil, de pesquisa, que era uma análise da relação entre trabalhadores terceirizados e efetivos na unidade de produção da Petrobrás em Sergipe. Uma vez vivendo aquilo ali um pouco com meus irmãos, eu notava uma diferença que se expressava nos crachás, nos uniformes deles, na maneira de se referir ao que era Petrobrás. Aí eu tenho acesso a uma literatura sobre trabalho no curso de Ciências Sociais, eu começo a desenhar melhor meus interesses, ainda tudo muito imaturo. São os primeiros experimentos de como fazer pesquisa. Eu esboço aí uma hipótese de 
trabalho, talvez muito crua ainda, mas é a que me persegue até hoje, que era essa relação de, no caso dos terceirizados, como é que eles se relacionavam com um trabalho que, em certa medida, eles se apropriavam como que pra dizer: "esse é o meu trabalho"; mas, em outra medida, também se afastavam desse trabalho por serem terceirizados, por terem uma relação distinta nos momentos de mobilização, de greves, o tratamento interno designado a essas pessoas. É verdade, se formos falar do contexto naquele momento, a empresa passava por um processo de enxugamento muito forte e de aumento do número de terceirizados, o que diferia muito das histórias que eu ouvia dos meus irmãos, do que era a empresa, a Petrobrás. Elas foram forjados como sendo essa categoria nativa de "efetivos", isso me marcou bastante.

Aí eu dou o passo seguinte, escrevo uma dissertação. É verdade que ainda muito influenciado por uma literatura de cunho marxista, muito marcada por essas ideias de alienação, de espoliação do trabalho... Começo a manusear essa literatura e, enfim, é um texto que, olhando hoje, eu não me reconheço. Eu sempre tenho uma relação de amor e ódio - acho que todos têm essa relação - com o que escrevo.

Eu faço um movimento um pouco maior no mestrado, ainda com esse background das histórias que meu pai sempre me contou. Ele inclusive foi um informante meu na tese. Volto a essa coisa dos terceirizados, mas num eixo muito específico, que era esses trabalhadores que atuam com a limpeza, com o asseio, com a manutenção no ambiente universitário.

\section{Iluminuras: Essa é a pesquisa de mestrado?}

Jaime: Essa é a pesquisa de mestrado. É esse trabalho de limpeza, daquele que, quando bem executado, deve ser invisível, as pessoas não podem ser vistas. Nós dizemos até mesmo, às vezes no linguajar comum, que "alguém limpou isso aqui" e ninguém nota quem foi... em geral, são essas pessoas que estão diretamente relacionadas com esse trabalho que de certa forma deve ser escondido; tido como bem feito quando ninguém percebe que alguém passou por ali e limpou. Então, mas perseguindo a mesma hipótese, que tipo de experiência se constrói à luz de um trabalho como esse? Experiência no sentido subjetivo. E aí, talvez, desenhando um pouco mais essa coisa de como é que os indivíduos "tratam" essa coisa, da concepção thompsoniana do "tratar", eu tava mais inquieto com essa equação interna que os indivíduos fazem. O lugar do dinheiro que me vem desse trabalho, o lugar que ele me propicia como modo de 
afirmação e inserção em outros ambientes que frequento. "Devo escondê-lo? Não devo escondê-lo? Devo me afirmar ou não?” e a relação com os coletivos, com os patrões, enfim.

Aí eu faço outro movimento no doutorado, agora analisando o que eu julgava, no início, ser uma situação de desemprego recorrente, o trabalho da cana de açúcar, o trabalho sazonal de cortadores de cana. Eu entendia que aquilo era uma situação de desemprego recorrente. A pessoa com quem eu trabalhei no doutorado, a professora Nadya Guimarães, estudava mercados de trabalho e essas situações propriamente de desemprego recorrente. Ela produz, inclusive, uma sociologia do desemprego, que está ligada a essas questões sobre análise dos mercados de trabalho. Nesse momento, eu queria também fazer um movimento, agora migratório, digamos, e sair do ambiente acadêmico de Sergipe para tentar estudar na Universidade de São Paulo. Quando eu me aproximo com essa proposta acabo mudando um pouco a temática, ou melhor, começo a lapidar melhor a questão de pesquisa que ali se apresentava. Por que, na verdade, aquilo que eu entedia como uma espécie de desemprego recorrente definia-se melhor como sendo uma situação de emprego recorrente. Aquilo que a Maria Aparecida de Moraes chama de "permanentemente temporário", ela usa uma metáfora que é um oxímoro. Era um universo novo do trabalho, agora tido como "rural", que eu estava ingressando. Um desafio também para Nadya, que não tem pesquisas sobre trabalho rural. Ela era mais do trabalho propriamente urbano, industrial, fabril essas coisas.

Volto a operar, então, com aquela hipótese que havia esboçado antes -de certa forma ela me persegue - quer dizer, uma vez que estou em face de uma situação de trabalho marcado pelo signo do estigma, um trabalho, talvez, para ser escondido, não revelado, como é que o próprio sujeito enfrenta essa situação de exploração, vivencia isso? É um recorte muito... se fosse numa fotografia seria aquela que quer mirar o detalhe, ou, ainda, um movimento visto na câmera lenta para análise. Como é que o sujeito equaciona essas demandas da vida frente a uma situação de trabalho como essa?

Iluminuras: Poderias pontuar como foi essa trajetória em termos de tempo e como foi o processo de transição de uma etapa de formação para a outra?

Jaime: Eu entro na graduação em Ciências Sociais em 1999 e saio em 2003. Fui estudante integral, full time. Não tive experiência de trabalho. Até tentei, mas não conseguia me empregar, porque as pessoas não sabiam o que um cientista social fazia. 
Enfim, tive bastante dificuldade com isso, mesmo para ensinar. Eu termino em 2003 a graduação e tento o mestrado em 2005. Nesse intervalo eu fiquei um pouco desiludido com as expectativas profissionais futuras... Também muito impactado pela trajetória de meus irmãos, que trabalharam muito cedo, sustentaram família e que de certa forma, me pressionavam sobre isso. Pesava sobre a minha trajetória um filho que estava fugindo um pouco daquela tradição de início prematuro no trabalho e de já "ganhar a vida" cedo. Era um outro contexto, é claro, diferente do que os meus irmãos viveram. E eu tento coisas curiosas nesse período. Prestei concurso para o Banco do Nordeste, Polícia Federal, Polícia Rodoviária Federal. Porque eu vivia em ambientes com colegas, enfim, que eram de outras áreas e todos nós estávamos apenas querendo ganhar algum dinheiro, ter alguma estabilidade. Pressionado, a gente atira para todos os lados. Não dá certo nada disso. Foi bom que não deu certo. É então que eu volto para o mestrado. No mestrado, tenho uma primeira inserção profissional na docência. Fui aprovado em concurso para professor substituto. Foi muito importante para mim. E entre o mestrado e o doutorado, eu termino o mestrado em 2007 e vou fazer o doutorado somente em 2010, lecionei em universidades privadas. Lecionei sempre Antropologia, curiosamente. O meu concurso para substituto foi em Antropologia e trabalhei com Antropologia Jurídica nas universidades privadas. Talvez por isso nutri outra característica que vai marcar a maneira como eu trato meus temas, que é um pouco essa coisa de borrar fronteiras. Eu nunca me senti confortável, talvez por ter feito a formação em Ciências Sociais, em me ver como Sociólogo, em me ver como Antropólogo, e sempre trabalhei com pessoas que reverberavam essa minha inquietação. Com pessoas que eu também não conseguia definir se aquelas trajetórias eram de sociólogos. A Nadya, por exemplo, se você pega a trajetória dela, é difícil você enquadrar. O José Sérgio Leite Lopes, o Moacir Palmeira, a Marilda Aparecida de Menezes, com quem venho trabalhando mais recentemente. São pessoas que alimentaram também em mim essa coisa de borrar fronteiras, e também eu sempre gostei muito de literatura. Eu acho até que eu queria borrar ainda mais essas fronteiras, abrindo um diálogo maior das Ciências Sociais com a Literatura, mas essas são as ideias que a gente trama em particular e muitas vezes, de maneira escondida, digamos. Eu acho que é um pouco isso, resumidamente, o que percorre esse meu enquadramento na trajetória acadêmica. 
Iluminuras: Agora adentramos nos principais argumentos da tua tese, um trabalho que reverbera a tua trajetória intelectual, tuas inquietações e hipóteses. Mas, primeiro, contextualizando um pouco teu universo de pesquisa.

Jaime: Minha tese começa com a escolha do universo de pesquisa: os mundos da cana-de-açúcar. Havia, nesse caso, uma justificativa que não era somente emocional, por ser Sergipano, fazer o trabalho em Sergipe. Esse é um argumento: de alguma forma estamos ligados com as nossas emoções, creio que isso de certa forma influencia a maneira como recortamos nosso tema e adentramos nele.

Mas, havia também um argumento de ordem mais operacional e analítica. Há uma lacuna na literatura sobre a cana-de-açúcar do que se passou em Sergipe. Há muita literatura sobre Pernambuco - que é o grande estado produtor do Nordeste - Alagoas e Paraíba. Sergipe havia ficado com uma lacuna, por isso eu voltei para os estudos na história, mais sobre o período do oitocentos, porque não mais se falava no período posterior, de falência das usinas em Sergipe. Como eu estava vivendo naquele contexto, eu vi o ressurgimento do trabalho e da lavoura canavieira em Sergipe. É verdade que isso ocorreu no bojo das mudanças nacionais no setor, com a tecnologia dos carros "flex fuel". Há um aquecimento da indústria nessa região que se nota atravessando a BR [rodovia]. A lavoura de cana-de-açúcar volta a crescer, então aquelas usinas que conheci quando pequeno, com meu pai, que estavam fechadas, voltam a operar, ou surgem novas usinas. É um universo que de 3 mil trabalhadores por safra passa a ter mais de 13 mil trabalhadores. Isso reconfigura as comunidades, os municípios em que essas usinas estavam presentes.
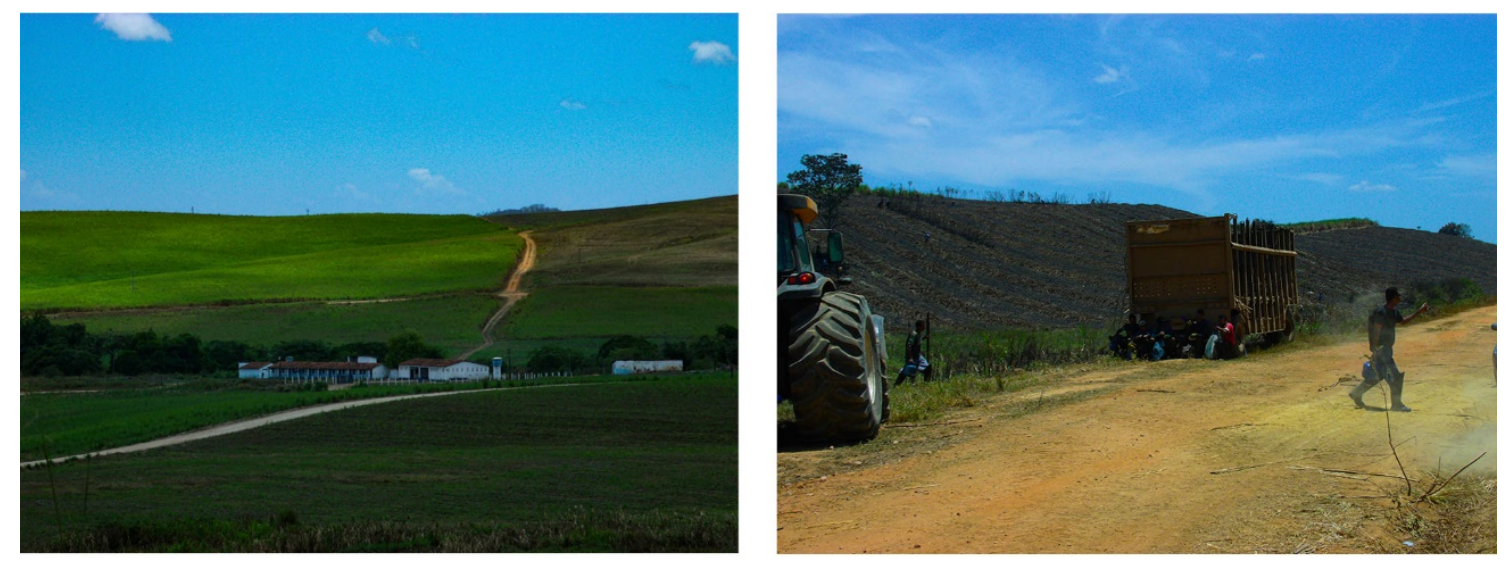

Imagem 2 - Fotos: Jaime Santos Junior. 
Iluminuras: Eram safras de monocultura de grandes dimensões, certo?

Jaime: Safras de monocultura na região da zona da mata, sobretudo no norte do estado. E que volta a ser perceptível a olho nu quando você cruza a BR 101. Onde antes não havia cana, volta a ter cana durante um período de interregno.

É verdade que Sergipe é um estado pequeno, é verdade que em termos de volume de produção, de mão-de-obra, era pouco expressivo se comparamos com outros estados. Mas a cadeia produtiva sucroalcooleira é nacional, Sergipe é um ator nesse processo, seja como demandante de força de trabalho, seja como ofertante de mão de obra. Pude perceber que havia trabalhadores em Sergipe que migravam para São Paulo, havia trabalhadores de outros estados que estavam em Sergipe na colheita, então ele, o estado, era um ator nesse processo. Meu universo era praticamente esse, com 6 usinas e mais ou menos 13 mil trabalhadores que estavam ali na época de colheita de cana.

Iluminuras: Lendo a tese, publicada em forma de livro sob o título "Na Trama das Identidades: Práticas sociais e imagens do trabalho no corte de cana”, (São Paulo: Annablume, 2017) penso que essa Sociologia que tu apresentas recupera alguns conceitos importantes como de "resistência", que bebe em outros campos do conhecimento, outras disciplinas. Queria que tu falasse um pouco sobre isso: quais são as influências desta "sociologia do trabalho" atenta às resistências? Qual o campo temático que te marca no estabelecimento de uma microssociologia, quem são as figuras que dialogaram contigo para tuas principais teses?

Jaime: Bom, uma primeira influência forte vem da literatura, da maneira como a literatura apresentou o tema. Sou leitor ávido do José Lins do Rego, por exemplo, do "Ciclo da cana[-de-açúcar]", uma coleção de livros sobre o que era o trabalho nos engenhos. Isso eu tinha lido na juventude. O Gilberto Freyre, em "Casa Grande \& Senzala" e "Sobrados e Mucambos". Foram coisas que eu li ainda na graduação. Certamente ficou algum caldo em mim, dessa narrativa que se confunde entre um estilo mais literário e aquele mais propriamente rigoroso, acadêmico. Porque virá daí alguns insights de pesquisa. E aí, quando você olha somente a trajetória dos estudos acadêmicos do trabalho na cana, no universo canavieiro no Brasil, você tem uma primeira inserção de antropólogos. É o projeto "Desenvolvimento regional comparado", do qual fazia parte o José Sérgio Leite Lopes, a Lygia Sigaud, o Moacir Palmeira, o Afrânio Garcia, a Beatriz Heredia. Todos eles vão para o Nordeste. O Otávio Velho vai 
para uma outra frente, nesse mesmo projeto, se não me engano, pesquisar migrantes na Amazônia. E deixaram trabalhos que hoje são divisores de água na área. Sucede que uma literatura posterior, mais recente e da sociologia do trabalho, eu diria que pesou muito a tinta nessa maneira, digamos, de um marxismo ortodoxo na forma de pensar a relação capital-trabalho e fotografar situações de trabalho como as do trabalho no corte de cana. Há um fortíssimo conjunto de estudos, para o qual esse era um universo que se restringia, ou se limitava, apenas a uma situação de "exploração limite", que remete, inclusive, ao trabalho em situação análoga à escravidão, porque existem casos de morte por exaustão. Essa literatura reverberava essa perspectiva de uma "sociologia da denúncia", que de fato é. Ao descrever uma situação de trabalho como essa, a primeira coisa com a qual você se depara é a denúncia. Mas, inquietado por aquelas coisas de “como é que eu, de carne e osso, vivo essa situação?”, volto a mobilizar velhas questões fazendo novas perguntas.

Penso que esse é um interessante exercício de pesquisa. Não necessariamente devemos partir, ou ter a ilusão de partir, de questões novas. Elas podem até já terem sido feitas, mas podem ser reformuladas à luz do novo sujeito que está fazendo e do novo contexto. Foi com esse espírito que retomei antigas pistas, para "pagar o pedágio", que o José Sérgio, a Beatriz e o Afrânio fizeram quando analisaram essa realidade na década de 1960, 1970; e que me parecia que já não estavam mais colocadas, dado o peso, no noticiário das ideias, dessa literatura que falava de "exploração do trabalho". Daí descende o núcleo da minha inquietação no trabalho sobre a cana. Então eu começo a tratar sobre a maneira como essas pessoas elaboram pequenos cálculos, para enfrentar as situações de trabalho in loco, lá naquele local, mas também para gerenciar os significados positivos e negativos associados ao trabalho. Seja para negá-lo, quando é o trabalho que ele reconhece, mas que não lhe permite uma afirmação positiva; é o trabalho que deve ser esquecido, que não deve ser comentado, que é, por vezes, verbalizado como palavrão. Mas, às vezes, pode ser afirmado numa acepção positiva, sobretudo pelos frutos que vêm do trabalho, os rendimentos monetários. Eu acho que não compete a mim dizer se aquilo era um bom uso do dinheiro, se aquilo era mais aquiescência do que rebeldia. Aí eu vou descendo um pouco mais o argumento, mexendo com as imagens associadas ao trabalho, para trabalhar com as formas de agência, da capacidade que temos para agir de outro modo. Entendo a agência, se quisermos uma conceituação bem simples, como essa capacidade que temos de agir de outra forma. 
Eis que chego nas "resistências cotidianas". Mas, formas de resistências que também, na literatura teórica, nem sempre são lidas como sendo resistências. Porque a mim não interessava somente, e ainda mais numa situação de trabalho como essa, onde opor-se a alguém pode colocar a vida em risco, as formas abertas de rebeldia, estive atento àquelas formas que não necessariamente pretendem a subversão da ordem. São formas de resistência que operam mais como barganhas, como negociações, como mediações possíveis entre "vender a alma ou não", "mentir" e fingir. Todas elas para mim podem ser acepções diversas do que eu estava lendo como resistências. É o momento em que me deparo com mais pessoas que também estavam fazendo isso.

É nesse momento que tenho contato com a Marilda Menezes. Tendo sido aluna do antropólogo americano James Scott, vinha dele essa proposta de leitura sobre resistências que não estavam calcadas nos atos com oponentes bem definidos e em confrontos abertos, mas aquilo que operava no silêncio, que não era trazido à tona. Era exatamente isso que havia tirado minhas noites de sono. Porque eu tinha visto isso em campo e visto menos aquelas formas mais contestatórias.

Mas, dizer isso era difícil. As pessoas supõem que diante de uma situação dessas há um certo automatismo em esperar dos sujeitos a rebelião, a inquietação, ou o oposto, a aceitação irrefletida, que também sempre me inquietou. Eu não encontrei nenhum idiota em campo. Muito pelo contrário, eu chegava em casa para ouvir os áudios e o desafio era que eu sempre sentia que estava deixando alguma coisa escapar ali. Algum sentido obscuro que estava nas entrelinhas das conversas, que eu não notei naquela ocasião, mas ouvindo e transcrevendo os áudios, volta e meia eu capturava algo. Que vinha exatamente dessas barganhas, dessa mediação que se faz entre patrão, colega de trabalho, gerente mais imediato. As "figuras do capital" estão personificadas em sujeitos de carne e osso. "Capital" talvez seja uma categoria mais para a gente, estudioso. Para dizer que algumas categorias são mais nossas do que dos nativos.

Por essa via eles mobilizam uma série de estratégias que operam nessa fronteira entre aquiescência e rebeldia, que eu estava lendo como resistência. As falas precisavam ser lidas ao contrário, às avessas, como propõe o Scott. Aquilo que era um sinal claro, uma evidência clara de "alienação", de "aceitação irrefletida", era na verdade uma sabedoria, para enganar inclusive a mim mesmo, como pesquisador.

Em 2016 reuni um grupo de historiadores, em São Paulo, que estudavam resistência escrava. Pude ver como eles já estavam operando nessa chave há muitos anos. Na História, essa "virada" já se deu a mais tempo, antes da Sociologia do 
Trabalho. Não se trabalha mais com a imagem do Zumbi, ou daquele que aceita passivamente. Existe uma série de mediações, de barganhas que a historiografia estava pondo luz e estava lendo, ou ousando ler, como atos de resistência.
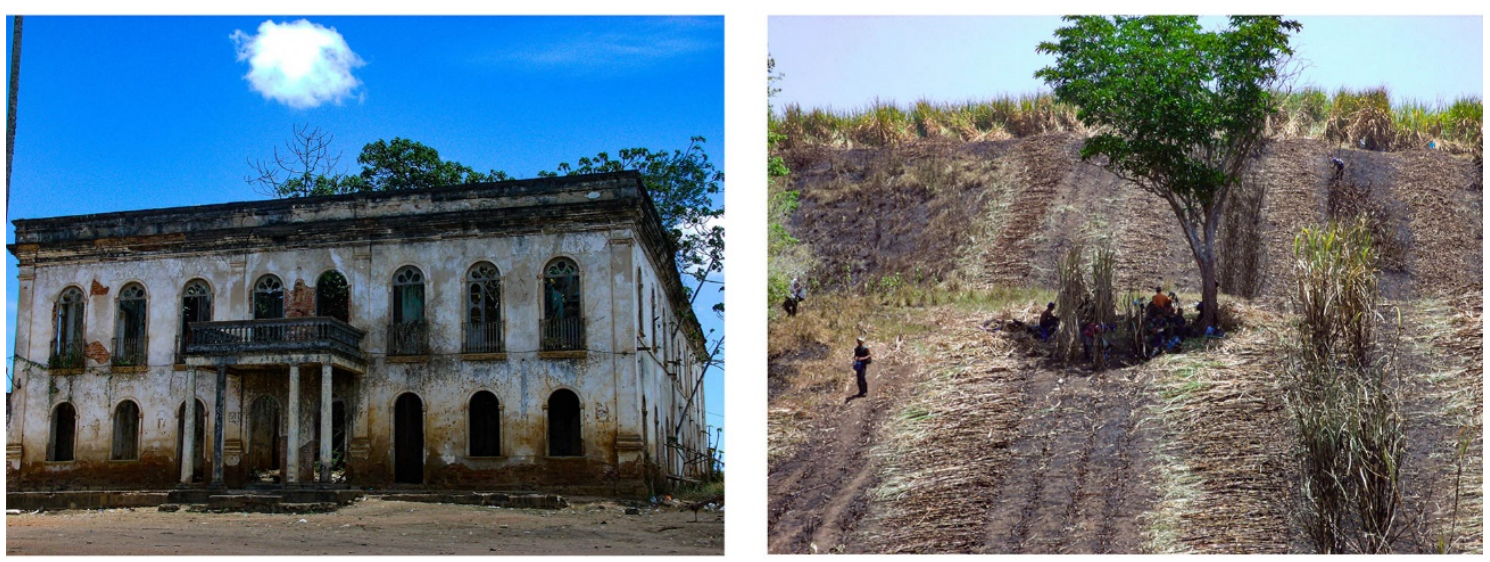

Imagem 3 - Fotos: Jaime Santos Junior

Iluminuras: Como se relaciona a produção de imagens fotográficas com essa concepção de resistência?

Jaime: Ainda que não tivesse o domínio da técnica de fotografia, fiz uns experimentos em levar a câmera para o campo e fotografar as situações que eu vivenciei. Seja nos eitos, quando eles estavam trabalhando, ou nos pontos de encontro dos trabalhadores reunidos para voltar aos seus estados de origem. Eu sempre tive um incomodo com a câmera porque eu acho que ela se aproxima muito de uma arma, eu preciso, inclusive, mirar para fazer as fotos. No entanto, havia algo mais sutil que estava sendo colocado em questão naquelas imagens. Agora não somente narradas, mas imagens propriamente do trabalho, que eu começo a perceber aos poucos e sinto que, às vezes, transmitem o que vou contar: elas não eram bem-vindas. Melhor dizendo, as fotografias captadas nessas situações de trabalho não eram bem aceitas. O semblante do sujeito, a minha própria presença ali, aquilo interferia sobremodo na maneira como esses indivíduos se representavam, sendo monossilábicos, sempre com a cabeça baixa, era uma fotografia quase como se eu já conhecesse o enredo. Eu posso fotografar para registro, há um valor nisso, mas o enredo eu já conheço, será esse. Diversa era a situação se fossem fotografados num momento de lazer. Eu faço fotografias de uma partida de futebol em que eu fui convidado a estar presente, eram só cortadores de cana, uma final de torneio. A imagem é outra, pareciam outras pessoas, inclusive eu 
confundia os que já conhecia. Muitas vezes eu já tinha conversado horas com o sujeito, ele passava por mim e eu não mais o reconhecia.

Tem uma coisa da fuligem da cana, de uma imagem borrada que o trabalho imprime nos corpos e borra também a nossa representação fotográfica que fazemos dessas pessoas. Então, eu sempre achava que a fotografia ali não era bem vinda, é por isso que você vê que algumas das fotos que faço são a distância. Eu faço dos alojamentos, algumas mais próximas dos ônibus, mas muito a distância, porque eu comecei a sentir o peso desse incômodo, daquela imagem que não era aquela que eles queriam ter de si próprios.

Isso me veio numa situação aparentemente banal, a de entrevistar um trabalhador depois do banho. Eu cheguei para a entrevista no momento em que ele tinha chegado do trabalho e me pediu para aguardar um pouco enquanto ele tomava banho, sucede que a pessoa que se apresentou depois do banho era completamente diferente. Literariamente exploro essa hipótese de que a água estava lavando uma imagem, mais do que o próprio corpo. Havia uma divisão entre mundos ali e a água era o marcador dessa fronteira. Eu penso que isso está relacionado às imagens que faço. Ou seja, se você pega qualquer imagem feita no universo da cana-de-açúcar você vai encontrar o que te disse. Isso não significa dizer que nos eitos não há momentos de lazer, há cachaça, brigas, brincadeiras entre eles. Portanto, há lazer também lá. O que borra as fronteiras e que, para mim, também expressam formas de resistir. 


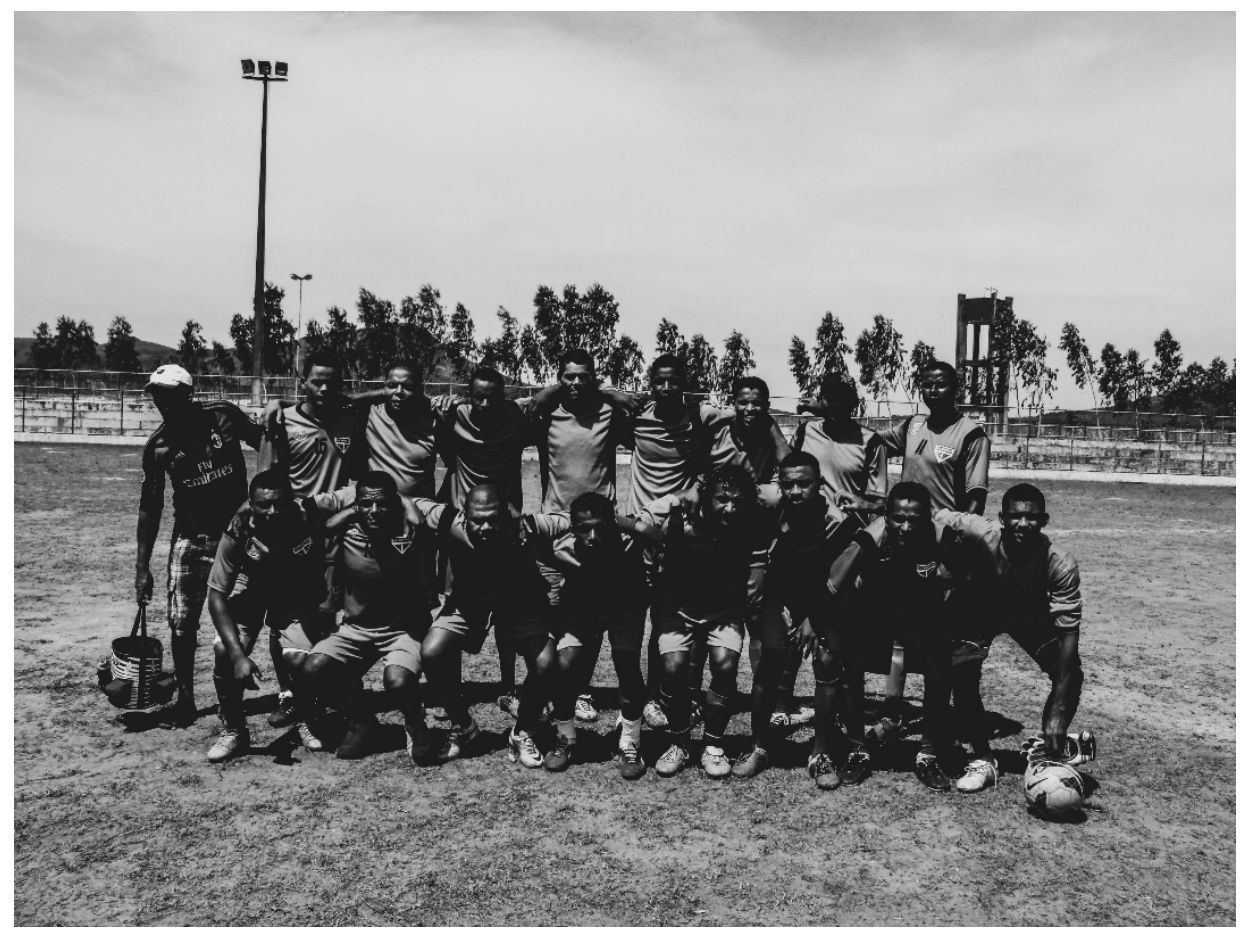

Imagem 4 - Foto: Jaime Santos Junior

Iluminuras: E esses interesses migram para teus novos projetos...

Jaime: Realmente, essas questões não morrem, eu guardo elas. Posteriormente, eu passo a trabalhar em outro projeto de pesquisa, agora com migrantes nordestinos que foram para a região do ABC Paulista nas décadas de 1960-1970. Alguns haviam retornado ao interior da Paraíba e outros estavam em São Paulo. Eles fizeram aquela trajetória mais tradicional, que marcou uma discussão sobre o que se convencionou chamar de "êxodo rural", em busca de trabalho nas cidades; portanto, saíram do universo rural e foram se empregar nas automotivas, nas metalúrgicas do ABC Paulista. Em verdade, esse era um projeto que a Marilda Menezes já vinha trabalhando, com pessoas que ela havia entrevistado 30 anos atrás. Eu propus um recorte com um novo projeto discutindo geração com os filhos dessas famílias.

A Marilda havia se aposentado da Universidade Federal de Campina Grande, onde foi professora, e estava como visitante sênior na Universidade Federal do ABC. Eu saio da Universidade de São Paulo também com aquele interesse em borrar fronteiras institucionais, não apenas intelectuais. Circular em outros ambientes acadêmicos, 
ventilar o que eu pensava com outras pessoas. Isso não correu por acaso, eu já havia trabalhado com a Marilda na pesquisa com os trabalhadores da cana-de-açúcar, ela foi uma interlocutora, e voltamos agora para esse novo projeto.

O que nós estávamos discutindo ali? Uma primeira questão está ligada a memória dessas migrações, das trajetórias de trabalho, que eram de indivíduos, mas também de famílias. E depois as transmissões intergeracionais desse legado. Mais uma vez eu estava interessado em compreender, volto a falar, a zona cinzenta, as fissuras, entre aquelas expectativas que viriam a ser atendidas pelos filhos e as que viriam a ser negadas. Eu perseguia a mesma questão com um novo recorte. Porque, creio, esse é o espaço da tensão, do conflito, mas é também o espaço do acordo e da aceitação. Fizemos trabalhos com essas pessoas, publicamos muitas coisas nessa área. O que me permitiu refinar um pouco mais os meus argumentos sobre o que estou lendo como resistências.

Mais recentemente venho trabalhando em um projeto, coordenado pelo José Sérgio Leite Lopes, que pretende comparar os ciclos de greves de canavieiros, em Pernambuco, e os ciclos de greves de metalúrgicos de São Paulo e do ABC Paulista, ambos ocorreram no final da década de 1970 e início de 1980 . Volto a trabalhar com memórias, com o recorte específico de memórias de mulheres metalúrgicas, memórias silenciadas. Há, portanto, uma ânsia em contar sobre a participação delas na história das greves, mas igualmente há um temor em revelá-las. Por envolver elementos mais complicados sobre como expor essas memórias.

Acreditamos que narrar seja também uma forma de resistir, de querer durar no tempo, como você bem coloca. Retorno a zona cinzenta mais uma vez. Sigo interessado, vendo essas trajetórias, nos aspectos que são lembrados, no que é esquecido, portanto dessa edição que será feita muito em negociação com a nossa presença.

Iluminuras: Uma última pergunta, para o fechamento. A Sociologia sempre estudou os movimentos sociais mais organizados, as classes sociais, agentes facilmente reconhecíveis e com resistências facilmente reconhecíveis. Agentes que manifestavam pública e coletivamente ações de resistência. Isso alicerça a Sociologia num certo papel ou engajamento político a favor dos menos favorecidos ou mesmo declarando apoio à atores politicos, como os movimentos operários, por exemplo. Qual é o papel de uma Sociologia agora focada nas microagências e em uma resistência não facilmente perceptivel e não necessariamente "transformadora da ordem”? 
Jaime: Bom, essa é uma boa pergunta. É uma pergunta que me persegue. Veja que eu apresento mais questões e dúvidas do que afirmações. Mais hipóteses de trabalho do que vaticínios sobre cenários. Eu acho que se queres buscar um papel para essa abordagem é, primeiro, trazer à tona ou ousar propor uma leitura diferenciada sobre essas situações que a princípio eram tidas como de pessoas que não se engajavam nesses movimentos abertos, tal como você alude na pergunta.

São pessoas que não se reconheciam - ou não eram reconhecidas - naqueles sujeitos constituídos pelos movimentos sociais, porque os movimentos sociais disputam as consciências, as almas e, nesse sentido, constituem sujeitos históricos. Não raro existem pessoas, pela própria trajetória de vida, que têm diferentes enquadramentos. Um exemplo, existem tensões entre se imaginar como "peão", ou como mãe de família. Certamente que há uma negociação de papéis na maneira de se apresentar. Eu acho que uma Sociologia ou uma Antropologia que fotografe essas situações, da "área cinzenta" como eu venho falando, acaba propondo uma nova leitura sobre aquilo que anteriormente era tido como situação de... vou usar o termo "alienação" para enquadrar melhor o que quero dizer.

Se essa forma de arguir for válida, creio que nós compreendemos melhor a atuação desses sujeitos. Claro que há colaboração, em certa medida irrefletida, não estou dizendo que tudo passa por um cálculo. Isso estabelece outro enfoque para os movimentos abertos, os grevistas, que dependem muito das ações que ocorrem no cotidiano. Permita-me aqui uma pequena digressão para falar da importância do cotidiano, ou sobre como ele importa nessa forma de arguir. Sucede que as ações que se passam nessa escala, a despeito do caráter recursivo da vida cotidiana, comportam contingências que desafiam as regularidades. São ambíguas e resistem ao enquadramento analítico, à normatividade, sendo assim catalisadoras de processos de mudança. Fecho esse pequeno parêntese.

Se me permite ousar, e retomando as histórias que ouvia do meu pai, vejo depois como elas estavam carregas de aspectos da vida cotidiana. Eu assumo a importância desse hábito de conversar no afã de flagrar insights que vêm de uma história do cotidiano. Penso que esse é o papel importante de uma sociologia que não quer ser apenas uma sociologia da denúncia. 


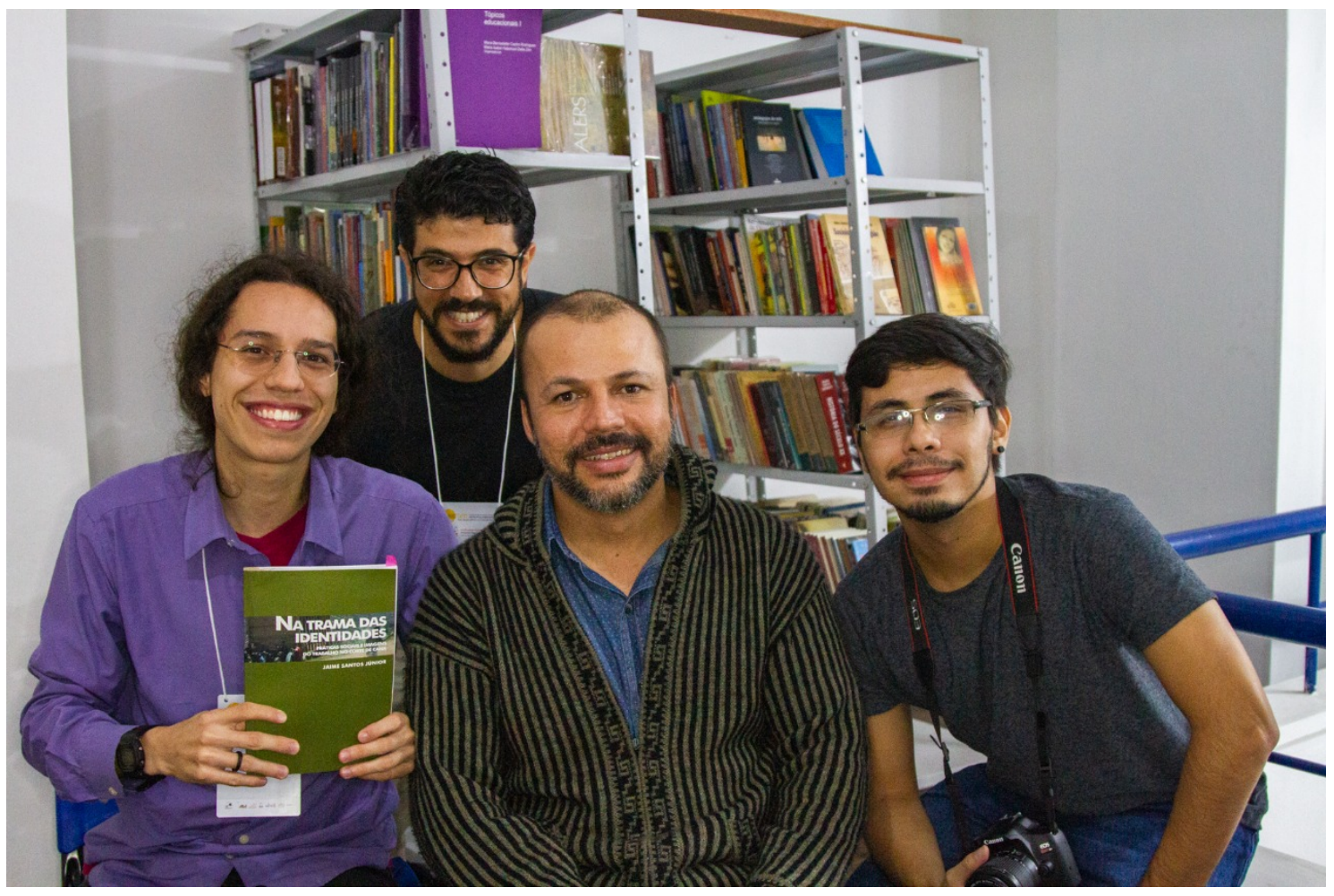

Imagem 5: Guillermo, Felipe, Jaime e Manoel, julho de 2019.

\section{REFERÊNCIAS}

GÓMEZ, Guillermo; BALDISSERA, Marielen; RODRIGUES, Felipe. Cornelia Eckert, "Chica". Estudos de trabalho, memória e imagem. Revista Latinoamericana de Antropología del Trabajo. Vol.3, No. 5.

Acesso em: http://www.ceil-conicet.gov.ar/ojs/index.php/lat/article/view/547/384

SANTOS JÚNIOR, Jaime. Nas Tramas das Identidades: práticas sociais e imagens do trabalho no corte de cana. São Paulo: Annablume, 2017.

SANTOS JÚNIOR, Jaime. Trabalho e resistências miúdas: astúcia, barganha e negociação. Revista Latinoamericana de Antropología del Trabajo, v. 2, p. 1-26, 2018. Acesso em: http://www.ceil-conicet.gov.ar/ojs/index.php/lat/article/view/363/205

SANTOS JÚNIOR, Jaime. A Dimensão Esquecida: a questão da agência no trabalho do corte da cana de açúcar. Caderno CRH, 31(83), 389-406, 2018. https://doi.org/10.1590/s0103-49792018000200014 
SANTOS JÚNIOR, Jaime ; THIBES, Mariana Zanata ; MENEZES, Marilda Aparecida de. Disjunções e ambivalências: famílias migrantes nordestinas no ABC paulista. Civitas: Revista de Ciências Sociais (Impresso), V. 19, p. 675-691, 2019. DOI: http://dx.doi.org/10.15448/1984-7289.2019.3.28647

THIBES, Mariana Z., MENEZES, Marilda Aparecida, \& SANTOS JÚNIOR, Jaime. (2018). Narrativas Assimétricas: Gênero, Família e Trabalho No ABC Paulista. Sociologia \& Antropologia, 8(2), 519 541. https://doi.org/10.1590/2238$\underline{38752017 \mathrm{v} 827}$

Recebido 25/03/2020

Aprovado 10/04/2020 